\title{
Simultaneous Estimation of Ambroxol Hydrochloride and Cetirizine Hydrochloride in Pharmaceutical Tablet Dosage Form by Simultaneous Equation Spectrophotometric Method: A Quality Control Tool for Dissolution Studies
}

\author{
Deepak Sharma, ${ }^{1}$ Mankaran Singh, ${ }^{2}$ Dinesh Kumar, ${ }^{3}$ and Gurmeet Singh ${ }^{4}$ \\ ${ }^{1}$ Department of Pharmaceutics, Rayat Bahra Institute of Pharmacy, Hoshiarpur, Punjab 146001, India \\ ${ }^{2}$ Quantum Solutions, Chandigarh 160036, India \\ ${ }^{3}$ CSIR Institute of Microbial Technology, Sector 39A, Chandigarh 160036, India \\ ${ }^{4}$ PDM School of Pharmacy, Karsindhu, Safidon Tehsil, Jind District, Haryana-126112, India \\ Correspondence should be addressed to Deepak Sharma; deepakpharmacist89@yahoo.com
}

Received 29 December 2013; Accepted 21 January 2014; Published 4 March 2014

Academic Editors: C. Desiderio, A. Niazi, and M. U. Özgür

Copyright (c) 2014 Deepak Sharma et al. This is an open access article distributed under the Creative Commons Attribution License, which permits unrestricted use, distribution, and reproduction in any medium, provided the original work is properly cited.

\begin{abstract}
Ambroxol Hydrochloride and Cetirizine Hydrochloride are used for the treatment of bronchitis, cough, and allergy. A simple, economical, accurate, and precise method for simultaneous estimation of Ambroxol Hydrochloride and Cetirizine Hydrochloride in tablet dosage form has been developed. Simultaneous equation method based on measurement of absorbance at two wavelengths, that is, $244 \mathrm{~nm}$ and $230 \mathrm{~nm}, \lambda_{\max }$ of Ambroxol Hydrochloride and Cetirizine Hydrochloride in $\mathrm{pH} 6.8$ phosphate buffer. Both of these drugs obeyed Beer-Lambert's law in the concentration range of $2-18 \mu \mathrm{g} / \mathrm{mL}$ for Ambroxol Hydrochloride and 2-20 $\mu \mathrm{g} / \mathrm{mL}$ for Cetirizine Hydrochloride. The high values of correlation coefficient $(R)$ indicated good linearity of calibration curve for both the drugs. The accuracy and precision of method were determined and the method was validated statistically. Result of percentage recovery study confirms the accuracy of proposed method. As per the ICH guidelines, the method validation parameters checked were linearity, accuracy, precision, and assay of drug formulation. Based on the results obtained, it can be concluded that the proposed simultaneous equation spectrophotometric method for simultaneous estimation of Ambroxol Hydrochloride and Cetirizine Hydrochloride is rapid, economical, accurate, precise, and reproducible. Hence, the proposed method can be employed for quantitative estimation of Ambroxol Hydrochloride and Cetirizine Hydrochloride from their tablet dosage form.
\end{abstract}

\section{Introduction}

Ambroxol Hydrochloride [AMB HCl] (Figure 1) officially in Indian Pharmacopoeia (IP) is chemically trans-4-[(2-amino3, 5-dibromobenzyl) amino]-cyclohexanol Hydrochloride. It is a white or yellowish crystalline powder. It is sparingly soluble in water, soluble in methanol, and practically insoluble in methylene chloride [1, 2]. Ambroxol Hydrochloride is a potent mucolytic and mucokinetic, capable of inducing bronchial secretion. It depolymerises mucopolysaccharides directly and by liberating lysosomal enzymes network of fibres in tenacious sputum is broken. It is particularly useful if mucus plugs are present. Ambroxol Hydrochloride
(AMB) is semisynthetic derivative of vasicine obtained from Indian shrub Adhatoda vasica. It is a metabolic product of bromhexine, used in a variety of respiratory disorders including chronic bronchitis and also used in the treatment of cough [3].

Cetirizine Hydrochloride [CET HCl] (Figure 2) is chemically [2-[4-[(4-chlorophenyl) phenylmethyl]-1piperazinyl]ethoxy]acetic acid and the active metabolite of the piperazine $\mathrm{H}_{1}$-receptor antagonist hydroxyzine. It is white or almost white powder, freely soluble in water, practically insoluble in acetone and in methylene chloride $[4,5]$. It is a nonsedative second generation antihistamine drug used in the treatment of seasonal allergic rhinitis, 
<smiles>Nc1c(Br)cc(Br)cc1CN[C@H]1CC[C@H](O)CC1</smiles>

Figure 1: Chemical structure of ambroxol hydrochloride.

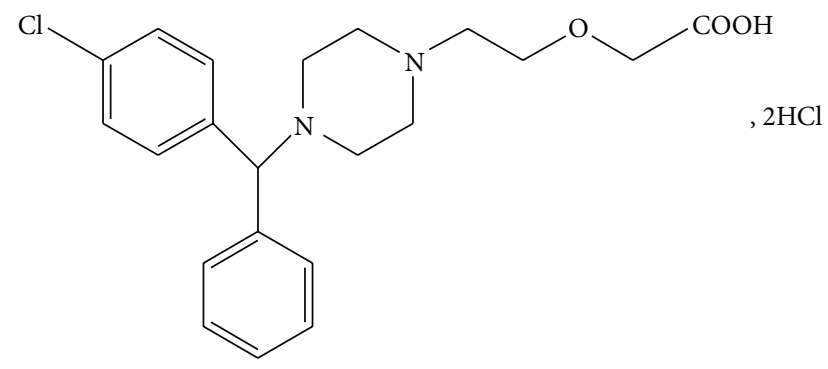

FIgure 2: Chemical structure of Cetirizine Hydrochloride.

perennial allergic rhinitis, and chronic urticaria and also used as adjuvant in seasonal asthma. Cetirizine inhibits the release of histamine and of cytotoxic mediators from platelets, as well as eosinophil chemotaxis during the secondary phase of allergic response [3].

The combination of these two drugs is not official in any pharmacopoeia; hence, no official method is available for the simultaneous estimation of Ambroxol Hydrochloride and Cetirizine Hydrochloride in their combined dosage form. From the literature survey, it was found that many chromatographic methods [HPTLC and RP-HPLC] have been reported for estimation of Ambroxol Hydrochloride and Cetirizine Hydrochloride in their combined dosage form and no spectrophotometric method for simultaneous estimation of Ambroxol Hydrochloride and Cetirizine Hydrochloride has been reported so far [6-13]. Hence an attempt has been made to develop new simultaneous equation spectrophotometric method which is simple, rapid, reproducible, and economical method for simultaneous estimation of Ambroxol Hydrochloride and Cetirizine Hydrochloride in tablet dosage form.

\section{Materials and Methods}

2.1. Apparatus. A double beam UV visible spectrophotometer (UV-1800 Shimadzu, Japan) was used. Absorption and overlain spectra of both test and standard solutions were recorded over the wavelength range of $200-400 \mathrm{~nm}$ using $1 \mathrm{~cm}$ quartz cell at fast scanned speed and fixed slit width of $1.0 \mathrm{~nm}$. All weighing of ingredients was done on digital weighing balance (DV 215 CD Ohaus, USA) and bath sonicator (PCI Analytical Pvt., Ltd.) was also used in study.

2.2. Reagents and Materials. Ambroxol Hydrochloride and Cetirizine Hydrochloride were supplied as gift sample by Trojan Pharma, Baddi, India. All other chemicals and reagents used were of analytical grade.

2.3. Selection of Common Solvent. Phosphate buffer of $\mathrm{pH}$ 6.8 was selected as common solvent for developing spectral characteristics of drug. The selection was made after assessing the solubility of the drugs in different solvents.

2.4. Preparation of Standard Stock Solution. Standard stock solutions of both Ambroxol Hydrochloride and Cetirizine Hydrochloride were prepared by dissolving $10 \mathrm{mg}$ of $\mathrm{AMB}$ $\mathrm{HCl}$ and $10 \mathrm{mg}$ of CET $\mathrm{HCl}$ separately in $10 \mathrm{~mL}$ of pH 6.8 phosphate buffer solution and sonicated for 15 minutes in bath sonicator and filtered through Whatman filter paper in order to get dilution of $1 \mathrm{mg} / 1 \mathrm{~mL}$, that is, $1000 \mu \mathrm{g} / \mathrm{mL}$.

2.5. Determination of Absorption ( $\lambda$ ) Maximas. By appropriate dilution of standard stock solutions of $\mathrm{AMB} \mathrm{HCl}$ and CET $\mathrm{HCl}$ with $\mathrm{pH} 6.8$ phosphate buffer, solution containing $10 \mu \mathrm{g} / \mathrm{mL}$ of $\mathrm{AMB} \mathrm{HCl}$ and $10 \mu \mathrm{g} / \mathrm{mL}$ of CET $\mathrm{HCl}$ was scanned separately and then in mixture form in the range of $200-400 \mathrm{~nm}$.

2.6. Calibration Plots for Ambroxol Hydrochloride and Cetirizine Hydrochloride. The calibration plots were constructed for Ambroxol Hydrochloride and for Cetirizine Hydrochloride using $\mathrm{pH} 6.8$ phosphate buffer solutions at their respective absorption maximas in order to find the linearity range of drugs at their respective absorption maximas.

2.7. Development of Simultaneous Equation. The absorbances were measured at the selected wavelengths and absorptivities for both drugs were determined at both wavelengths. The concentrations of drugs in sample solution were determined by using following formula:

$$
\begin{aligned}
& A_{1}=a x_{1} C_{\mathrm{A}}+a y_{1} C_{\mathrm{C}}, \quad \text { At } 244 \mathrm{~nm}, \\
& A_{2}=a x_{2} C_{\mathrm{A}}+a y_{2} C_{\mathrm{C}}, \quad \text { At } 230 \mathrm{~nm},
\end{aligned}
$$

where $C_{\mathrm{A}}$ and $C_{\mathrm{C}}$ are the concentration of Ambroxol Hydrochlorideand Cetirizine Hydrochloride, respectively, $A_{1}$ and $A_{2}$ are absorbance at $244 \mathrm{~nm}$ and $230 \mathrm{~nm}$, respectively, $a x_{1}$ and $a x_{2}$ are absorptivities of Ambroxol Hydrochlorideat $244 \mathrm{~nm}$ and $230 \mathrm{~nm}$, respectively and $a y_{1}$ and $a y_{2}$ are absorptivities of Cetirizine Hydrochloride at $244 \mathrm{~nm}$ and $230 \mathrm{~nm}$, respectively.

2.8. Validation of Proposed Method. The optimized UV spectrophotometric method was completely validated according to the procedure described in ICH guidelines. The performance parameters evaluated for the method were linearity, precision, accuracy, limits of detection and quantitation, and assay of drug. 
TABLE 1: Absorbance and absorptivity values of Ambroxol Hydrochloride at $\lambda_{\max } 244 \mathrm{~nm}$ and $230 \mathrm{~nm}$, respectively.

\begin{tabular}{|c|c|c|c|c|c|}
\hline $\begin{array}{l}\text { Serial } \\
\text { number }\end{array}$ & $\begin{array}{l}\text { Concentration } \\
(\mu \mathrm{g} / \mathrm{mL})\end{array}$ & ${ }^{*}$ Absorbance at $244 \mathrm{~nm} \pm$ S.D & ${ }^{*}$ Absorbance at $230 \mathrm{~nm} \pm \mathrm{S} . \mathrm{D}$ & Absorptivity at $244 \mathrm{~nm}$ & Absorptivity at $230 \mathrm{~nm}$ \\
\hline 1 & 2 & $0.044 \pm 0.001$ & $0.034 \pm 0.002$ & 0.022 & 0.017 \\
\hline 2 & 4 & $0.101 \pm 0.002$ & $0.079 \pm 0.004$ & 0.025 & 0.020 \\
\hline 3 & 6 & $0.152 \pm 0.003$ & $0.119 \pm 0.002$ & 0.025 & 0.020 \\
\hline 4 & 8 & $0.197 \pm 0.001$ & $0.152 \pm 0.003$ & 0.025 & 0.019 \\
\hline 5 & 10 & $0.248 \pm 0.002$ & $0.190 \pm 0.002$ & 0.025 & 0.019 \\
\hline 6 & 12 & $0.297 \pm 0.004$ & $0.229 \pm 0.001$ & 0.025 & 0.019 \\
\hline 7 & 14 & $0.343 \pm 0.002$ & $0.262 \pm 0.001$ & 0.025 & 0.019 \\
\hline 8 & 16 & $0.401 \pm 0.002$ & $0.309 \pm 0.003$ & 0.025 & 0.019 \\
\hline \multirow[t]{2}{*}{9} & 18 & $0.452 \pm 0.003$ & $0.347 \pm 0.002$ & 0.025 & 0.019 \\
\hline & & & Average & $a x_{1}=0.025$ & $a x_{2}=0.019$ \\
\hline
\end{tabular}

*Each value is the average of three determinations.

TABLE 2: Absorbance and absorptivity values of Cetirizine Hydrochloride at $\lambda_{\max } 244 \mathrm{~nm}$ and $230 \mathrm{~nm}$, respectively.

\begin{tabular}{lccccc}
\hline $\begin{array}{l}\text { Serial } \\
\text { number }\end{array}$ & $\begin{array}{c}\text { Concentration } \\
(\mu \mathrm{g} / \mathrm{mL})\end{array}$ & ${ }^{*}$ Absorbance at $244 \mathrm{~nm} \pm \mathrm{S} . \mathrm{D}{ }^{*}$ Absorbance at $230 \mathrm{~nm} \pm$ S.D & Absorptivity at 244 nm Absorptivity at 230 $\mathrm{nm}$ \\
\hline 1 & 2 & $0.019 \pm 0.004$ & $0.077 \pm 0.002$ & 0.0095 & 0.0385 \\
2 & 4 & $0.025 \pm 0.003$ & $0.135 \pm 0.003$ & 0.0063 & 0.0375 \\
3 & 6 & $0.045 \pm 0.002$ & $0.209 \pm 0.003$ & 0.0075 & 0.0348 \\
4 & 8 & $0.051 \pm 0.005$ & $0.267 \pm 0.001$ & 0.0054 & 0.0334 \\
5 & 10 & $0.054 \pm 0.003$ & $0.332 \pm 0.004$ & 0.0058 & 0.0332 \\
6 & 12 & $0.069 \pm 0.002$ & $0.393 \pm 0.002$ & 0.0056 & 0.0328 \\
7 & 14 & $0.078 \pm 0.001$ & $0.468 \pm 0.002$ & 0.0056 & 0.0334 \\
8 & 16 & $0.089 \pm 0.002$ & $0.530 \pm 0.003$ & 0.0056 & 0.0054 \\
9 & 18 & $0.100 \pm 0.003$ & $0.585 \pm 0.001$ & $0.653 \pm 0.002$ & 0.0325 \\
10 & 20 & $0.107 \pm 0.001$ & Average & $a y_{1}=0.0063$ & $a y_{2}=0.0338$ \\
\hline
\end{tabular}

${ }^{*}$ Each value is the average of three determinations.

2.8.1. Linearity. The linearity of measurement was evaluated by analyzing different concentrations of the standard solution of Ambroxol Hydrochlorideand Cetirizine Hydrochloride.

2.8.2. Precision (Repeatability). The precision of the instrument was checked by repeated scanning and measurement of absorbance of solutions $(n=6)$ for Ambroxol hydrochlorideand cetirizine hydrochloride $(10 \mu \mathrm{g} / \mathrm{mL}$ for both drugs) without changing the parameter of the proposed spectrophotometry method. The intraday and interday precision studies (intermediate precision) were carried out by estimating the corresponding responses 3 times on the same day and on 3 different days for three different concentrations of $\mathrm{AMB} \mathrm{HCl}$ $(8,12$, and $16 \mu \mathrm{g} / \mathrm{mL})$ and $\operatorname{CET~} \mathrm{HCl}(6,10$, and $14 \mu \mathrm{g} / \mathrm{mL})$, and the results are reported in terms of relative standard deviation.

2.8.3. Limit of Detection and Limit of Quantitation. The limit of detection (LOD) and limit of quantitation (LOQ) were separately determined based on standard deviation of the $y$ intercept and the slope of the calibration curve by using (3) and (4), respectively:

$$
\begin{aligned}
& \mathrm{LOD}=\frac{3.3 \delta}{S}, \\
& \mathrm{LOQ}=\frac{10 \delta}{S},
\end{aligned}
$$

where, $\delta$ is standard deviation of $y$-intercept and $S$ is slope of calibration curve.

2.8.4. Recovery (Accuracy) Studies. In order to check the accuracy, reproducibility, and precision of the proposed method, recovery study was carried out by taking standard mixture solution of both AMB and CET and absorbances were determined at $244 \mathrm{~nm}$ and $230 \mathrm{~nm}$, respectively.

2.8.5. Assay of Drug. Ten tablets $(200 \mathrm{mg})$ were powdered in a mortar pestle and the blend equivalent to $7.5 \mathrm{mg}$ of Ambroxol Hydrochloride and $5 \mathrm{mg}$ of ctirizine Hydrochloride was 
TABLe 3: Optical characteristics of Ambroxol Hydrochloride and Cetirizine Hydrochloride.

\begin{tabular}{lcc}
\hline Optical characteristics & Ambroxol Hydrochloride & Cetirizine Hydrochloride \\
\hline$\lambda_{\max }(\mathrm{nm})$ & 244 & 230 \\
Beer-Lambert's law limit $(\mu \mathrm{g} / \mathrm{mL})$ & $2-18$ & $2-20$ \\
Regression equation $(y=m x+c)$ & $y=0.025 x-0.002$ & $y=0.032 x+0.011$ \\
Slope $(m)$ & 0.025 & 0.032 \\
Intercept $(c)$ & 0.002 & 0.011 \\
Correlation coefficient $(R)$ & 0.999 & 0.999 \\
LOD $(\mu \mathrm{g} / \mathrm{mL})$ & 0.450 & 0.457 \\
LOQ $(\mu \mathrm{g} / \mathrm{mL})$ & 1.424 & 1.386 \\
Precision $(\% \mathrm{RSD})$ & & 0.381 \\
Repeatability & 0.452 & 0.416 \\
Intraday & 0.374 & 0.863 \\
Interday & 0.942 & \\
\hline
\end{tabular}

TABle 4: Recovery studies for Ambroxol Hydrochloride and Cetirizine Hydrochloride.

\begin{tabular}{lccc}
\hline $\begin{array}{l}\text { Ambroxol Hydrochloride } \\
(\mu \mathrm{g} / \mathrm{mL})\end{array}$ & $\begin{array}{c}\text { Cetirizine Hydrochloride } \\
(\mu \mathrm{g} / \mathrm{mL})\end{array}$ & $\begin{array}{c}\text { Ambroxol Hydrochloride } \\
\text { (mean percentage recovery) }\end{array}$ & $\begin{array}{c}\text { Cetirizine Hydrochloride } \\
(\text { mean percentage recovery) }\end{array}$ \\
\hline 8 & 6 & $96.67 \pm 2.53$ & $98.63 \pm 1.76$ \\
12 & 10 & $95.43 \pm 3.14$ & $99.79 \pm 3.25$ \\
16 & 14 & $98.80 \pm 1.15$ & $101.5 \pm 3.29$ \\
\hline
\end{tabular}

Results are shown in \pm S.D $(n=3)$.

weighed and dissolved in $100 \mathrm{~mL}$ of $\mathrm{pH} 6.8$ phosphate buffer solutions. The solution was sonicated for 15 minutes, filtered through Whatman filter paper, and suitably diluted with $\mathrm{pH}$ 6.8 phosphate buffer and the drug content was analyzed from simultaneous equation method by using double beam UV spectrophotometer at $244 \mathrm{~nm}$ and $230 \mathrm{~nm}$, respectively.

\section{Results and Discussion}

3.1. Determination of Absorption Maximas. Wavelengths of absorption maximas were determined for both drugs. AMB $\mathrm{HCl}$ showed absorption maximas one at $244 \mathrm{~nm}$ and another one at $308 \mathrm{~nm}$, respectively. $244 \mathrm{~nm}$ was selected as $\lambda_{\max }$ of Ambroxol Hydrochloride. CET $\mathrm{HCl}$ showed maximum absorbance at $230 \mathrm{~nm}$ with reference to British Pharmacopoeia and Indian Pharmacopoeia.

From the overlain spectra of Ambroxol Hydrochlorideand Cetirizine Hydrochloride (Figure 3), two wavelengths $244 \mathrm{~nm}$ and $230 \mathrm{~nm}$ and $\lambda_{\max }$ of Ambroxol Hydrochlorideand Cetirizine Hydrochloride were selected for further spectroscopic studies. Therefore, for simultaneous equation method, wavelengths selected for analysis were $244 \mathrm{~nm}$ for $\mathrm{AMB} \mathrm{HCl}$ and $230 \mathrm{~nm}$ for CET $\mathrm{HCl}$.

3.2. Calibration Plots for Ambroxol Hydrochloride and Cetirizine Hydrochloride. From the calibration plot of Ambroxol Hydrochloride and Cetirizine Hydrochloride at their respective absorption maximas, the linearity was observed in the concentration range of $2-18 \mu \mathrm{g} / \mathrm{mL}$ for Ambroxol Hydrochlorideand $2-20 \mu \mathrm{g} / \mathrm{mL}$ for Cetirizine Hydrochloride, which were validated by the least square method. Coefficient of correlation $(R)$ was found to be 0.999 for both Ambroxol Hydrochloride and Cetirizine Hydrochloride as given in Table 3. The high value of correlation coefficient $(R)$ also indicates good linearity of calibration curve for both drugs.

3.3. Development of Simultaneous Equation. The absorptivity values were found approximately the same for all the concentrations; hence both drugs obeyed Beer-Lambert's law in indicated concentration range as given in Tables 1 and 2 .

The following equation was designed for the simultaneous estimation of Ambroxol Hydrochloride and Cetirizine Hydrochloride in tablet dosage form:

$$
\begin{aligned}
& A_{1}=0.025 C_{\mathrm{A}}+0.0063 C_{\mathrm{C}}, \quad \text { At } 244 \mathrm{~nm}, \\
& A_{2}=0.019 C_{\mathrm{A}}+0.0338 C_{\mathrm{C}}, \quad \text { At } 230 \mathrm{~nm},
\end{aligned}
$$

where $C_{\mathrm{A}}$ and $C_{\mathrm{C}}$ are the concentration of Ambroxol Hydrochlorideand Cetirizine Hydrochloride, respectively, $A_{1}$ and $A_{2}$ are absorbance values at $244 \mathrm{~nm}$ and $230 \mathrm{~nm}$, respectively, 0.025 and 0.019 are absorptivities of Ambroxol Hydrochlorideat $244 \mathrm{~nm}$ and $230 \mathrm{~nm}$, respectively and 0.0063 and 0.0338 are absorptivities of Cetirizine Hydrochloride at $244 \mathrm{~nm}$ and $230 \mathrm{~nm}$, respectively. By solving (5) and (6) simultaneously, the concentration of Ambroxol Hydrochloride and Cetirizine Hydrochloride in tablet dosage form can be calculated.

3.4. Validation of Proposed Method. The validation parameters were studied at all wavelengths for the proposed method. The optical characteristics such as $\lambda_{\text {max }}$, Beer-Lambert's law 
TABLE 5: Drug content uniformity of Ambroxol Hydrochloride and Cetirizine Hydrochloride.

\begin{tabular}{|c|c|c|c|c|c|c|}
\hline Serial number & $\begin{array}{c}\text { Absorbance at } \\
244 \mathrm{~nm} \pm \text { S.D } \\
\left(A_{1}\right)\end{array}$ & $\begin{array}{c}\text { Absorbance at } \\
230 \mathrm{~nm} \pm \text { S.D } \\
\left(A_{2}\right)\end{array}$ & $\begin{array}{c}\mathrm{C}_{\mathrm{A}} \\
(\mu \mathrm{g} / \mathrm{mL}) \mathrm{C}_{\mathrm{C}} \\
(\mu \mathrm{g} / \mathrm{mL})\end{array}$ & $\begin{array}{c}\text { Drug } \\
\text { content of } \\
\text { Ambroxol } \\
\text { Hydrochlo- } \\
\text { ride (\%age ) } \\
\pm \text { S.D }\end{array}$ & $\begin{array}{l}\text { Drug content of Cetirizine } \\
\text { Hydrochloride (\%age ) } \pm \text { S.D }\end{array}$ & \\
\hline 1 & 0.206 & 0.284 & 7.13 & 4.39 & 95.06 & 87.80 \\
\hline 2 & 0.201 & 0.287 & 6.87 & 4.62 & 91.60 & 92.40 \\
\hline 3 & 0.207 & 0.285 & 7.17 & 4.40 & 95.60 & 88.00 \\
\hline Mean $(n=3)$ & $0.205 \pm 0.003$ & $0.285 \pm 0.002$ & & & $94.09 \pm 2.17$ & $89.40 \pm 2.60$ \\
\hline
\end{tabular}

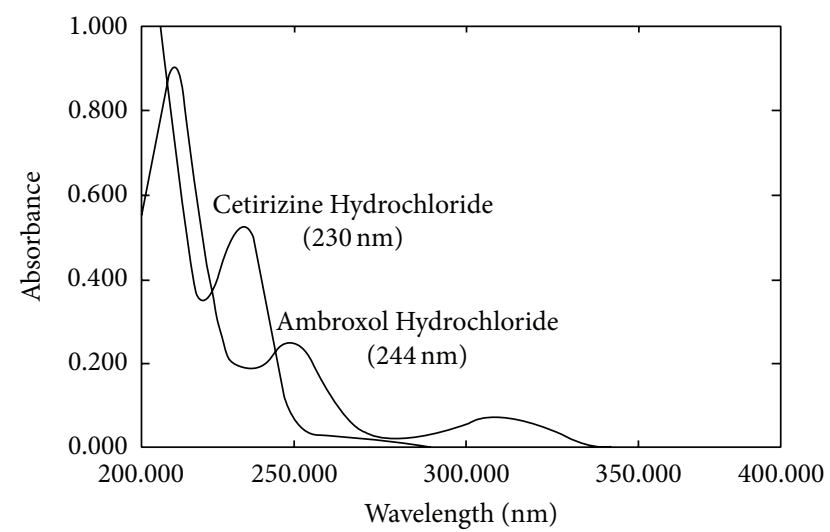

FIGURE 3: Overlain spectra of mixture of Ambroxol Hydrochlorideand Cetirizine Hydrochloride solution.

limit, Regression equation, slope, intercept, correlation coefficient, LOD, and LOQ were calculated and are summarized in Table 3.

As per the ICH guidelines, the method validation parameters checked were linearity, accuracy, precision, and assay of drug. Precision studies were carried out to study the intraday and interday variations of the responses. Instrumental precision study was carried out by repeatability study. The low RSD value and LOD and LOQ values indicate that the method is precise and sensitive. The recovery studies and assay of drug for Ambroxol Hydrochloride and Cetirizine Hydrochloride were given in Tables 4 and 5 .

Based on the results obtained, it can be concluded that the proposed spectrophotometric method for simultaneous estimation of Ambroxol Hydrochloride and Cetirizine Hydrochloride is rapid, economical, accurate, precise, and reproducible. The utility of the developed method has been demonstrated by analysis of combined dose tablet formulation. Hence, the proposed method can be employed for quantitative estimation of Ambroxol Hydrochloride and Cetirizine Hydrochloride in combined tablet dosage form. Simultaneous equation method can be used to carry out dissolution study in tablet formulation of these drugs.

\section{Conclusion}

The developed spectrophotometric method, that is, simultaneous equation method is found to be simple, sensitive, accurate, and precise and can be used for routine analysis of Ambroxol Hydrochloride and Cetirizine Hydrochloride in combined table dosage form. The developed method was validated as per ICH guidelines. The results demonstrated that simultaneous equation method by spectrophotometer could be useful technique for estimation of Ambroxol Hydrochloride and Cetirizine Hydrochloride in tablet dosage form and cost of analysis is less as compared to RP-HPLC method. Hence simultaneous equation method can be conveniently used for routine quality control analysis of $\mathrm{AMB} \mathrm{HCl}$ and $\mathrm{CET} \mathrm{HCl}$ in its pharmaceutical tablet formulations.

\section{Conflict of Interests}

The authors declare that they do not have any financial or personal relationships with other people or any other organizations that could inappropriately influence this research work.

\section{Acknowledgment}

The authors are thankful to Trojan Pharma, Baddi, India, for providing gift samples of drugs.

\section{References}

[1] Indian Pharmacopoeia, Government of India Ministry of Health and Family Welfare, vol. 3, Controller of Publications, Delhi, India, p. 83, 2007.

[2] British Pharmacopeia, Medicinal Substances, vol. 1-2, pp. 265268, 2009.

[3] K. D. Tripathi, Essential of Medical Pharmacology, Jaypee Brothers Medical Publishers, New Delhi, India, 6th edition, 2008.

[4] Indian Pharmacopoeia, Government of India Ministry of Health and Family Welfare, vol. 3, Controller of Publications, Delhi, India, pp. 274-275, 2007.

[5] British Pharmacopeia, Medicinal Substances, vol. 1-2, pp. 1198$1202,2009$. 
[6] S. Gopalakrishnan, T. A. Chitra, A. Aruna, and A. Chenthilnathan, "Development of RP-HPLC method for the simultaneous estimation of ambroxol hydrochloride, cetirizine hydrochloride and antimicrobial preservatives in combined dosage form," Der Pharma Chemica, vol. 4, no. 3, pp. 1003-1015, 2012.

[7] M. Maithani, R. Raturi, V. Gautam, D. Kumar, A. Gaurav, and R. Singh, "Simultaneous estimation of ambroxol hydrochloride and cetirizine hydrochloride in tablet dosage form by RP-HPLC method," International Journal of Comprehensive Pharmacy, vol. 2, no. 3, pp. 1-3, 2010.

[8] T. P. Kumar, M. A. Haque, K. P. Kumar, G. Nivedita, and V. P. Diwan, "Simultaneous determination of cetirizine hydrochloride and ambroxol hydrochloride in combined dosage form by using RP-HPLC method," American Journal of PharmTech Research, vol. 2, no. 6, pp. 716-723, 2012.

[9] M. G. Raja, G. Geetha, A. Sankaranarayanan, K. M. G. Raju, and P. S. Kumar, "Simultaneous and stability indicating method for determination of cetrizine hydrochloride and ambroxol hydrochloride in syrup," International Journal of Pharmaceutical Sciences and Research, vol. 3, no. 8, pp. 2658-2663, 2012.

[10] N. M. Bhatia, S. K. Ganbavale, M. S. Bhatia, H. N. More, and S. U. Kokil, "RP-HPLC and spectrophotometric estimation of ambroxol hydrochloride and cetirizine hydrochloride in combined dosage form," Indian Journal of Pharmaceutical Sciences, vol. 70, no. 5, pp. 603-608, 2008.

[11] B. A. Patel, S. G. Patel, D. P. Patel, B. H. Patel, and M. M. Patel, "Stability indicating HPTLC method development and validation for estimation of ambroxol hydrochloride and cetirizine dihydrochloride in combine tablet dosage form," International Research Journal of Pharmacy, vol. 2, no. 3, pp. 9599, 2011.

[12] P. Arora, V. Arora, and S. Jain, "Simultaneous estimation of cetirizine dihydrochloride and ambroxol hydrochloride in pharmaceutical formulation by a novel HPLC method," International Journal of Pharmaceutical Sciences and Research, vol. 2, no. 12, pp. 3149-3151, 2012.

[13] P. Venkateshwari, G. V. S. Kumar, S. B. Puranik et al., "Development of stability indicating RP-HPLC method for simultaneous estimation of ambroxol hydrochloride and levocetirizine dihydrochloride," International Journal of Advances in Pharmaceutical Analysis, vol. 2, no. 2, pp. 34-40, 2012. 

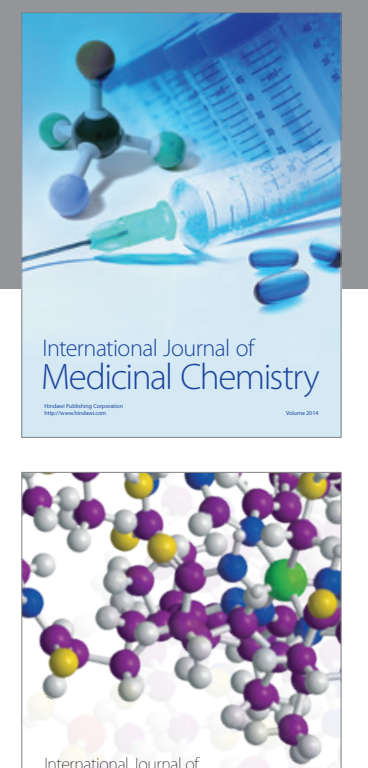

\section{Carbohydrate} Chemistry

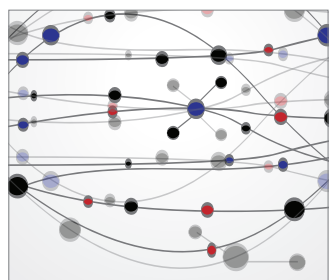

The Scientific World Journal
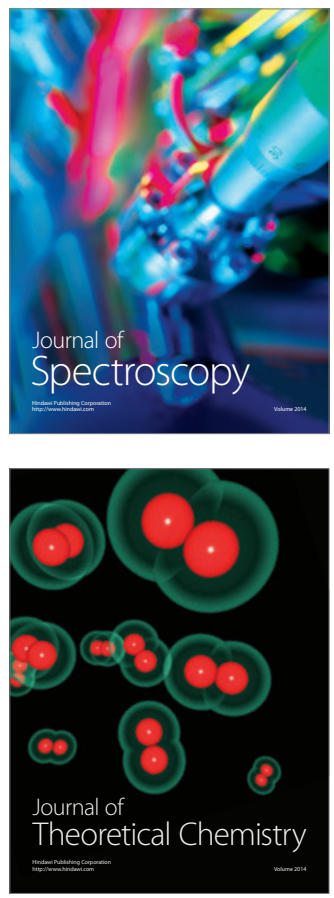
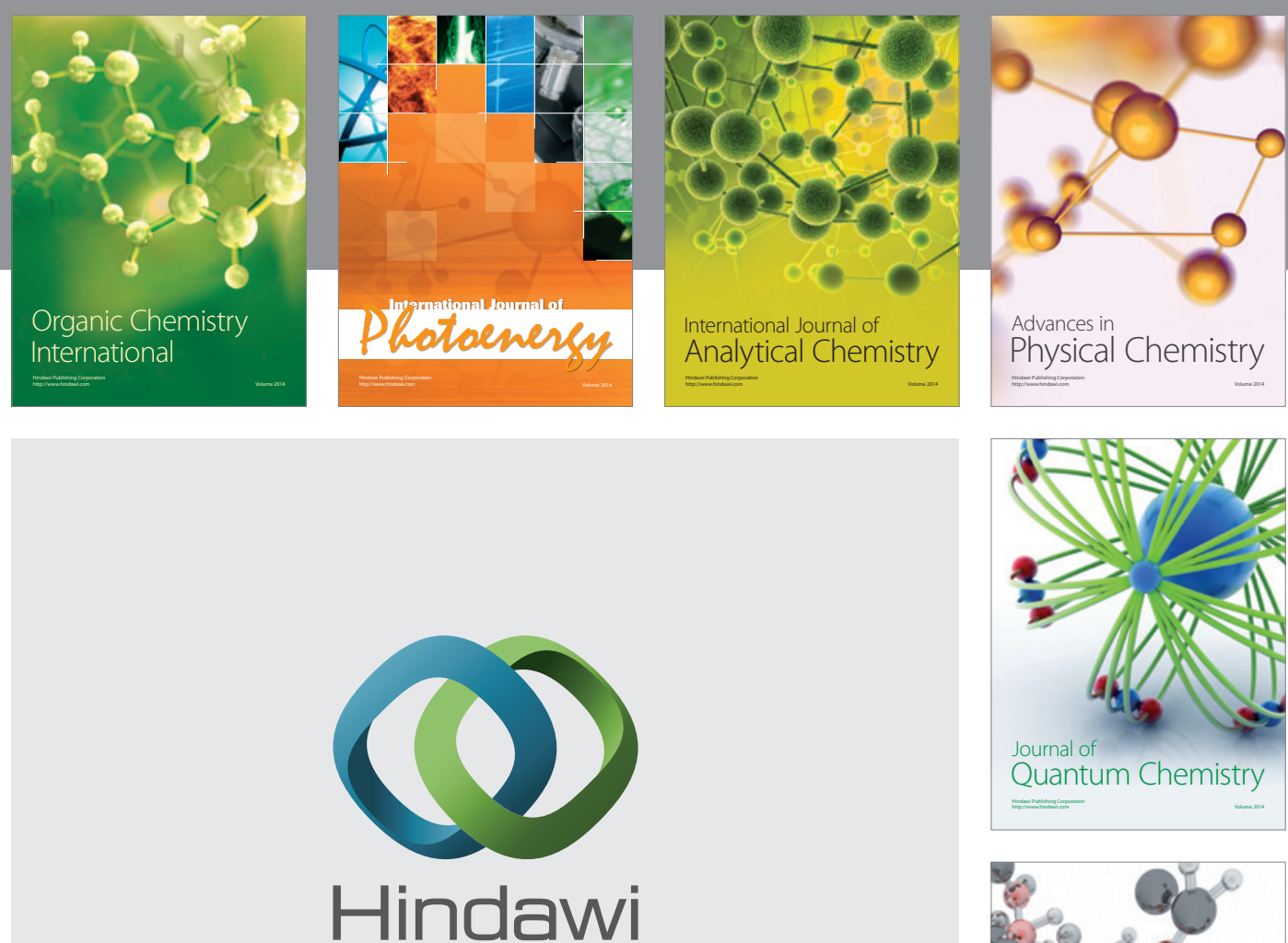

Submit your manuscripts at

http://www.hindawi.com

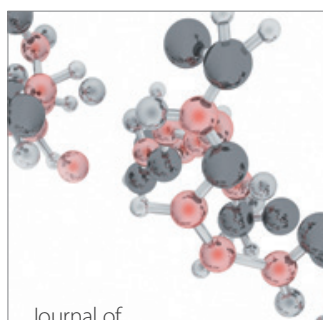

Analytical Methods

in Chemistry

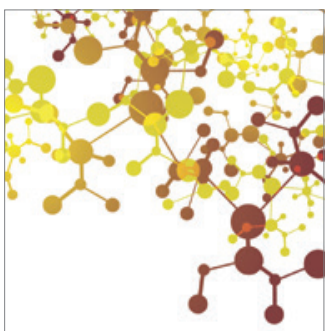

Journal of

Applied Chemistry

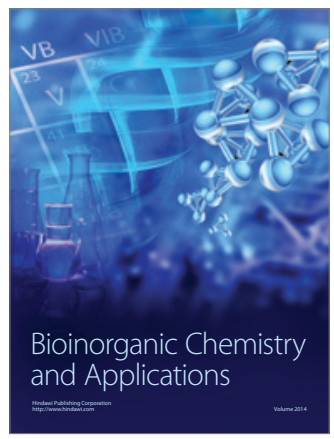

Inorganic Chemistry
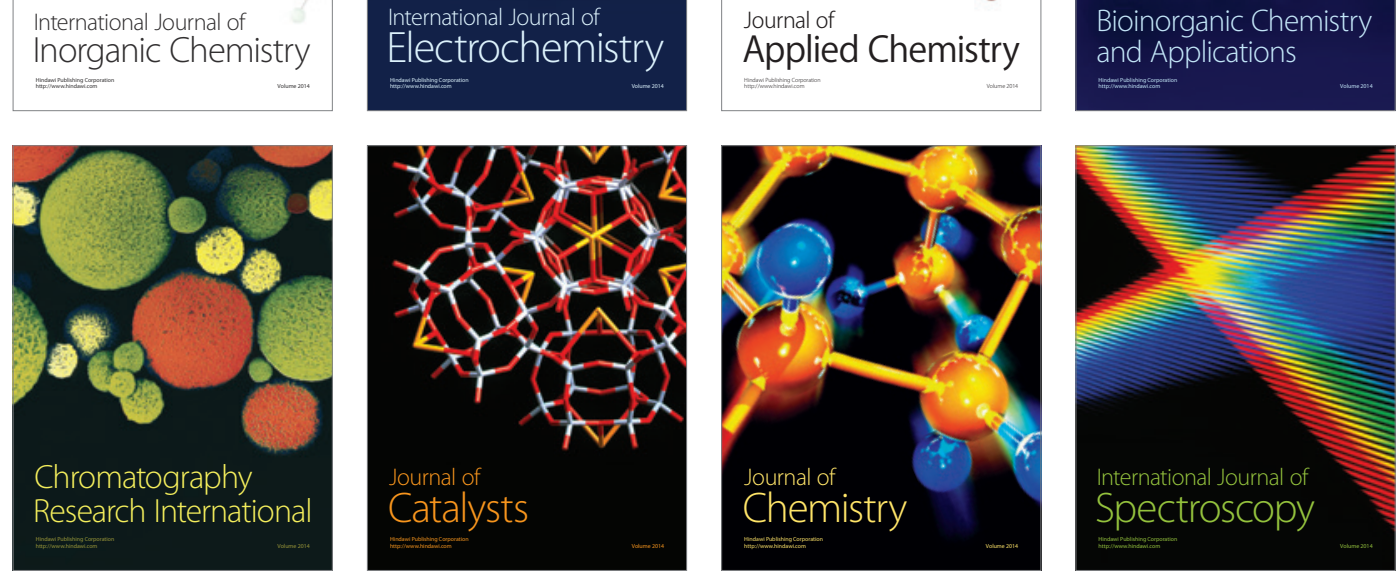